\title{
A New Whey Cheese Analogue Made from Whey Protein Concentrate and Vegetable Fat with 15\% Olive Oil
}

\author{
Evangelia Zoidou, loanna Andreadaki, Theophilos Massouras and Stelios Kaminarides*
}

Department of Food Science and Hunan Nutrition, Agricultural University of Athens, Greece

${ }^{*}$ Corresponding author: Stelios Kaminarides, Department of Food Science and Human Nutrition, Laboratory of Dairy Science and Technology, Agricultural University of Athens, lera Odos 75, Votanikos, 11855 Athens, Greece, E-mail: skamin@aua.gr

\begin{abstract}
In this study a whey cheese analogue was made using as basic ingredients whey protein concentrate 65 and vegetable fat with $15 \%$ olive oil. The product was enriched with thyme leaves, film packed and then subjected to heat treatment. The overall characteristics of the product were investigated during 25 days storage at $4^{\circ} \mathrm{C}$ and compared with those of traditional whey cheese. The whey cheese analogue had a lower microflora than traditional whey cheese, a smaller percentage of saturated and a greater percentage of mono- and poly-saturated fatty acids and remained organoleptically and texturally acceptable after 25 days storage at $4^{\circ} \mathrm{C}$ whereas traditional whey cheese deteriorated. The whey cheese analogue was characterized as a new whey cheese easy to produce with improved health enhancing properties, acceptable textural characteristics, rich aroma profile and extended shelf-life.
\end{abstract}

\section{Keywords}

Whey cheese analogue, Whey protein concentrate, Vegetable fat, Whey cheese

\section{Introduction}

Imitation cheeses or cheese analogues are cheese-like products in which milk fat, milk protein or both are partially or wholly replaced by non milk-based components to produce a specific cheese variety. They are manufactured by blending various edible fats/oils, proteins, other ingredients and water into a smooth homogenous blend with the aid of heat, mechanical shear and emulsifiers [1]. The market of analogues has grown recently due to their simplicity of production, and the substitution of lacteal ingredients by cheaper vegetable ones, factors that allow for a reduction in product manufacturing costs [2].

The production of whey cheeses is based on the denaturation and coagulation of the water soluble milk proteins present in the whey when it is heated at temperatures above $85^{\circ} \mathrm{C}$ [3]. Of all Greek whey cheeses, Myzithra is the one that is produced in the largest quantity throughout the country. It is a soft cheese, usually made from the whey of hard or semi-hard cheeses or derived after Feta cheese production from either ewe or a mixture of ewe and goat milk. Myzithra is more a dietary product compared with other Greek traditional cheeses, containing $15-19 \%$ fat and a moisture content that is not greater than $70 \%$ [4]. Due to the high moisture content, low concentration of salt and $\mathrm{pH}$ close to 6, Myzithra, is susceptible to microbial spoilage and consequently has a limited shelf-life $[5,6]$. Whey Protein Concentrates (WPCs) are whey protein powder preparations which contain 35$80 \%$ total protein and variable quantities of moisture, lactose, ash, fat, $\mathrm{K}, \mathrm{Cl}, \mathrm{Ca}, \mathrm{P}, \mathrm{Na}, \mathrm{Mg}$ and non protein nitrogen, while the total microorganism count is influenced by the following processing steps: pasteurization, ultrafiltration, spray-drying and packaging. WPCs are widespread due to their functionality and nutritional value, as they contain high concentrations of bioactive proteins, essential amino acids, e.g. branched chain amino acids (leucine, isoleucine, and valine) and sulphur amino acids (methionine, cysteine) and they have antioxidant properties [7].

Fat consumption has been shown to be associated with an increased risk of heart and artery disease [8]. Milk fat contains over $70 \%$ saturated acyl groups and of these, laurate, myristate and palmitate are considered particularly atherogenic [9]. The amount of fat intake is considered equally important to the balance of saturated to unsaturated fatty acids, so that diets abundant in mono and polyunsaturated fats are considered healthy. Vegetable oils are a good source of healthy unsaturated fats and are generally cholesterolfree. Substitution of milk fat by vegetable fat in dairy products is an option for obtaining products with a healthier saturated/unsaturated fat balance [10]. However, the incorporation of vegetable oils causes modifications in cheese microstructure and textural behavior $[11,12]$.

Taking into consideration the importance of utilizing WPCs and the demand for healthy products that are consistently available in the market all year round, the aim of this study was to prepare a whey cheese analogue using as basic ingredients whey protein concentrate (WPC) and a vegetable fat blend with $15 \%$ olive oil. Olive oil has many beneficial properties (contains vitamins $\mathrm{E}$ and $\mathrm{A}$ acting antioxidants contributing to longevity, prevents the formation of blood clots in the heart arteries, prevents fat accumulation in the liver, etc). In order to improve flavour, the product was enriched with thyme leaves and to extend its shelf life it was film packed before being subjected to heat treatment. The product was stored at $4^{\circ} \mathrm{C}$ for 25 days and analyzed for physicochemical, microbiological, rheological and organoleptic characteristics in comparison with traditional whey cheese.

\section{Materials and Methods}

\section{Production of whey cheese analogue}

Whey cheese analogue was prepared so as to adjust the fat in dry

Citation: Zoidou E, Andreadaki I, Massouras T, Kaminarides S (2016) A New Whey Cheese Analogue Made from Whey Protein Concentrate and Vegetable Fat with 15\% Olive Oil. J Nutri Med Diet Care 2:017

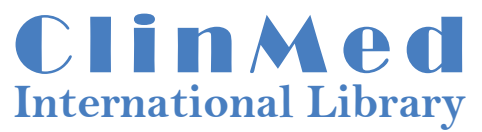

Received: June 04, 2016: Accepted: August 25, 2016: Published: August 27, 2016 Copyright: ( 2016 Zoidou E, et al. This is an open-access article distributed under the terms of the Creative Commons Attribution License, which permits unrestricted use, distribution, and reproduction in any medium, provided the original author and source are credited. 
matter to about $50 \%$ and moisture content to about $67 \%$, as in control traditional whey cheese, using the following formula: (1) $61.3 \%$ distilled water, (2) 17.2\% Whey Protein Concentrate 65\% (WPC-65) from the Greek "Epirus Protein Company" containing 65\% serum proteins, $23 \%$ lactose, $3.8 \%$ fat, $3.3 \%$ ash, calcium $3.6 \mathrm{~g} / \mathrm{kg}$, phosphate $3.3 \mathrm{~g} / \mathrm{kg}$, sodium $2.7 \mathrm{~g} / \mathrm{kg}$, potassium $6.6 \mathrm{~g} / \mathrm{kg}$, magnesium $0.8 \mathrm{~g} /$ $\mathrm{kg}$, (3) $1.7 \%$ skim milk powder containing $1 \%$ fat, $51 \%$ lactose, $27 \%$ caseins, $6.6 \%$ serum proteins and $8.5 \%$ ash, (4) $19.8 \%$ vegetable fat containing $15 \%$ olive oil, (5) $0.4 \%$ emulsifier/stabilizer (E/S) powder (Cremodan SE 334 VEG type, Danisco). The WPC and milk powder were mixed thoroughly in the water under stirring and gradually heating to $65^{\circ} \mathrm{C}$. At $65^{\circ} \mathrm{C}$, vegetable fat, then $\mathrm{E} / \mathrm{S}$ and finally fresh thyme leaves were added to the mix and agitated to produce a thick, smooth, homogenous mixture. The mixture was placed in cylindrical polyethylene film packages of $200 \mathrm{~mL}$, tied firmly with string at the ends and heated in a water bath under stirring at $90^{\circ} \mathrm{C}$ for $30 \mathrm{~min}$. Then it was cooled under running water to room temperature and maintained refrigerated at $4^{\circ} \mathrm{C}$ for 25 days.

\section{Production of traditional whey cheese}

Traditional whey cheese was produced according to the following procedure described by Anifantakis [13]: whey derived from sheep and caprine milk in a ratio $70 / 30$ following the production of Halloumi cheese [14] was collected, filtered to remove any existing curd grain, weighed and poured into a circular cheese vat. The whey was gradually heated under continuous stirring up to $85^{\circ} \mathrm{C}$. When small curd particles of whey proteins appeared, the temperature was increased to $90^{\circ} \mathrm{C}$, while stirring was reduced and finally stopped when a very thin layer of coagulum formed on the surface of the whey. The curd was cooked at $90^{\circ} \mathrm{C}$ for $30 \mathrm{~min}$, then transferred gradually by a perforated ladle into moulds of cheese cloth and hung from a pole in a well-ventilated room at $20^{\circ} \mathrm{C}$ for $3 \mathrm{~h}$ to drain. Afterwards, the whey cheese was wrapped in paper and maintained refrigerated at $4^{\circ} \mathrm{C}$ for 25 days.

\section{Cheese sampling}

Five replicates of each type of cheese were produced. The cheeses were analyzed 1 day after production and after 25 days of storage at $4^{\circ} \mathrm{C}$. All analyses were performed in triplicate. All reagents and chemicals were of analytical grade.

\section{Microbiological analysis}

Cheeses were examined for their total bacteria microflora, yeasts and moulds and coliforms. $10 \mathrm{~g}$ of the cheese sample were blended with $90 \mathrm{~mL}$ of $2 \%$ (w/v) sterilized sodium citrate (Merck, Darmstadt, Germany) for $2 \mathrm{~min}$ in a Stomacher Lab Blender 400 (Seward Medical, London, UK) and then subjected to serial dilutions using $0.1 \%(\mathrm{w} / \mathrm{v})$ Ringer solution (Oxoid, Hampshire, England).

The following microbiological tests were performed: total aerobic bacteria on PCA Agar (Difco, Michigan, USA) at $30^{\circ} \mathrm{C}$ for $72 \mathrm{~h}$ [15], yeasts and moulds on YGC-agar (Merck, Darmstadt, Germany) at $25^{\circ} \mathrm{C}$ for 5 days [16], coliforms on Violet Red Bile Agar (Oxoid, Hampshire, England) at $37^{\circ} \mathrm{C}$ for $24 \mathrm{~h}$ [17]. All the counts were expressed as colony forming units per gram of cheese $\left(\mathrm{cfu} \mathrm{g}^{-1}\right)$.

\section{Physicochemical analysis}

Cheeses samples were analyzed for total proteins [18], total solids [19], fat [20], ash [21], acidity [22], minerals [23] and lactose [24]. The $\mathrm{pH}$ was measured by a $\mathrm{pH}$ meter (632, Metrohm, Germany).

\section{Analysis of volatile compounds}

The volatile compounds profile of cheese samples was measured 1 day after production using SPME GC/MS analysis. Cheese samples (4 g) were homogenized with $2 \mathrm{~mL}$ of saturated $\mathrm{Na}_{2} \mathrm{SO}_{4}$ aqueous solution and $100 \mu \mathrm{L}$ of an internal standard aqueous solution containing 0.77 g L-1 cyclohexanone (Sigma-Aldrich Quvmica, Alcobendas, Spain). Aliquots ( $3 \mathrm{~g}$ ) of the homogenates were placed in to $22 \mathrm{~mL}$ vials sealed with PTFE/silicone septa (Supelco, Bellefonte, PA) through which the SPME syringe needle (bearing a 50/30 $\mu \mathrm{m}$ DVB/CAR/PDMS fiber
Supelco, Bellefonte, PA, USA) was introduced. The samples were stirred continuously on a stir plate revolving at $750 \mathrm{rpm}$. Fiber was exposed to the headspace above the sample for $30 \mathrm{~min}$ at $65^{\circ} \mathrm{C}$. The absorbed volatiles were then analyzed by GCMS (Shimadzu GC-17 A, MS QP5050 and capillary column HP-INNOWax $60 \mathrm{~m}, 0.25 \mathrm{~mm}$ i.d, $0.25 \mu \mathrm{m}$ film thickness, J\&W Scientific, Agilen Technologies). Interface, quadruple and ion source temperatures were 250,280 and $230^{\circ} \mathrm{C}$ respectively. The oven temperature was set at $45^{\circ} \mathrm{C}$ for $5 \mathrm{~min}$, increased to $150^{\circ} \mathrm{C}$ at a rate of $5^{\circ} \mathrm{C} \mathrm{min}^{-1}$, then raised at $7^{\circ} \mathrm{C} \mathrm{min}{ }^{-1}$ to $220^{\circ} \mathrm{C}$ and held at $250^{\circ} \mathrm{C}$ for $20 \mathrm{~min}$. Helium was used as carrier

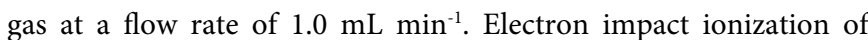
MS was used at a voltage of $70 \mathrm{eV}$. The mass range was $\mathrm{m} / \mathrm{z} 40-500$. Identification was effected by comparison with standards and using the NIST (National Institute of Standards and Technology, United States) spectrum library. The volatile compounds were quantified by dividing the peak areas of the compounds of interest by the peak area of the IS, multiplying this ratio by the initial concentration of the IS (expressed as ppm). The peak areas were measured from the full scan chromatograph using total ion current (TIC).

\section{Fatty acids analysis}

For fatty acids analysis, lipid extraction was performed [25] and fatty acids were then methylated by base-catalyzed methynolysis of milk fat [26]. The fatty acid methyl esters (FAME) were analyzed by GC/MS (Shimadzu chromatograph GC-17A, equipped with flame ionization detector (FID) and capillary column SP-2340 $30 \mathrm{~m}, 0.25 \mathrm{~mm}$ id, $0.2 \mu \mathrm{m}$ film thickness, Supelco Bellefonte, $\mathrm{PA})$. Injection and detector temperatures were $250^{\circ} \mathrm{C}$ and $270^{\circ} \mathrm{C}$ respectively. The injection volume was $1 \mu \mathrm{L}$ (split 1:50). The oven temperature was set at $45^{\circ} \mathrm{C}$ for $5 \mathrm{~min}$ after injection, increased to $150^{\circ} \mathrm{C}$ at a rate of $5^{\circ} \mathrm{C} \mathrm{min}^{-1}$, held there for $5 \mathrm{~min}$ and then raised at $7^{\circ} \mathrm{C} \mathrm{min}^{-1}$ to $220^{\circ} \mathrm{C}$ and held there for $20 \mathrm{~min}$. Helium was used as carrier gas at a flow rate of $1.0 \mathrm{~mL} \mathrm{~min}{ }^{-1}$. The FAME identification was performed by comparing with standards (FAME Mix Supelco, Sigma-Aldrich) and quantification was performed using Dionnex Chromeleon software.

\section{Textural evaluations}

The textural profile analysis (TPA) of the cheeses was assessed with a Shimadzu testing instrument, model AGS-500 NG (Shimadzu Corporation, Kyoto, Japan) equipped with a $5-\mathrm{kg}$ load cell, as described by Kaminarides and Stachtiaris [27]. The following six textural parameters were calculated: Hardness $(\mathrm{N})$, defined as the peak force $(\mathrm{H})$ during the first compression cycle (first bite), is the force necessary to attain a given deformation. Cohesiveness $(\mathrm{N} \mathrm{mm})$, defined as the ratio of the positive area under the curve during the second compression to that during the first compression. Adhesiveness $(\mathrm{N} \mathrm{mm})$, defined as the negative force area for the first bite, is the work necessary to overcome the attractive forces between the surfaces of the cheese and the plunger with which the cheese comes into contact. Elasticity ( $\mathrm{mm})$, defined as the ratio of the base line of the positive curve during the second compression to that during the first compression, is the height that the cheese recovers during the time that elapses between the end of the first and the start of the second bite. Gumminess $(\mathrm{N})$, which is the product of hardness $\mathrm{X}$ cohesiveness, is the energy required to disintegrate a cheese to a state ready for swallowing. Chewiness $(\mathrm{N})$, which is the product of gumminess $\mathrm{X}$ elasticity is the energy required to masticate a cheese to a state ready for swallowing.

\section{Organoleptic evaluation}

Cheese samples were graded by a taste panel of the Dairy Laboratory of the Agricultural University of Athens. Panel members evaluated cheese for appearance, body and texture, and flavour (odor and taste) using a 10-point scale, with 1 being the worst and 10 the best quality. More importance was given to flavour and to body and texture than to appearance of the cheese as advised by IDF standard [28], by multiplying their scores by 5 and 4 , respectively. The total score was obtained by adding the scores of the three attributes. An excellent cheese obtained a total score of 100 . 
Table 1: Microbial counts ( $\log 10 \mathrm{cfu} / \mathrm{g}$ ) of the two types of whey cheese 1 day after production and after 25 day's storage*.

\begin{tabular}{|l|l|l|l|l|}
\hline \multirow{2}{*}{ Microbial group } & \multicolumn{2}{l|}{ Traditional whey cheese } & \multicolumn{2}{l|}{ Whey cheese analogue } \\
\cline { 2 - 5 } & Day 1 & Day 25 & Day 1 & Day 25 \\
\hline Total bacteria & $3.61^{\mathrm{a}} \pm 0.43$ & $8.94^{\mathrm{c}} \pm 0.20$ & $1.77^{\mathrm{a}} \pm 0.48$ & $6.37^{\mathrm{b}} \pm 0.2$ \\
\hline Coliforms & $<1^{\mathrm{a}}$ & $7.60^{\mathrm{b}} \pm 0.27$ & $<1^{\mathrm{a}+}$ & $<1^{\mathrm{a}}$ \\
\hline Yeasts & $2.04^{\mathrm{b}} \pm 0.53$ & $6.28^{\mathrm{c}} \pm 0.57$ & $<1^{\mathrm{a}}$ & $<1^{\mathrm{a}}$ \\
\hline
\end{tabular}

Values are means \pm standard error of mean. Different letters $(a, b, c)$ in the same row are indicative of a significant statistical difference $(P<0.05)$ between the values.

"Not found in the sample dilution $10^{-1}$

Table 2: Physicochemical characteristics of the two types of whey cheese 1 day after production*.

\begin{tabular}{|l|l|l|}
\hline $\begin{array}{l}\text { Physicochemical } \\
\text { characteristics }\end{array}$ & Traditional whey cheese & Whey cheese analogue \\
\hline Fat $\%$ & $18.39^{\mathrm{a}} \pm 2.04$ & $16.27^{\mathrm{a}} \pm 0.49$ \\
\hline Moisture \% & $66.86^{\mathrm{a}} \pm 1.58$ & $67.34^{\mathrm{a}} \pm 0.65$ \\
\hline Ash \% & $1.01^{\mathrm{b}} \pm 0.06$ & $0.81^{\mathrm{a}} \pm 0.02$ \\
\hline Total protein \% & $11.93^{\mathrm{a}} \pm 0.47$ & $12.01^{\mathrm{a}} \pm 0.16$ \\
\hline $\mathrm{pH}$ & $6.25^{\mathrm{a}} \pm 0.07$ & $6.20^{\mathrm{a}} \pm 0.24$ \\
\hline Lactose \% & $3.17^{\mathrm{a}} \pm 0.28$ & $4.66^{\mathrm{b}} \pm 0.05$ \\
\hline $\mathrm{Ca}(\mathrm{mg} / 100 \mathrm{~g}$ cheese $)$ & $246.71^{\mathrm{b}} \pm 25.97$ & $90.04^{\mathrm{a}} \pm 9.60$ \\
\hline $\mathrm{Mg}(\mathrm{mg} / 100 \mathrm{~g}$ cheese) & $18.90^{\mathrm{a}} \pm 1.60$ & $17.57^{\mathrm{a}} \pm 2.11$ \\
\hline $\mathrm{K}(\mathrm{mg} / 100 \mathrm{~g}$ cheese $)$ & $77.89^{\mathrm{a}} \pm 6.33$ & $132.71^{\mathrm{b}} \pm 15.66$ \\
\hline $\mathrm{Na}(\mathrm{mg} / 100 \mathrm{~g}$ cheese $)$ & $14.83^{\mathrm{a}} \pm 0.52$ & $64.23^{\mathrm{b}} \pm 6.24$ \\
\hline
\end{tabular}

*Values are means \pm standard error of mean. Different letters $(a, b)$ in the same row are indicative of a significant statistical difference $(P<0.05)$ between the values.

\section{Statistical analysis}

Data were subjected to analysis of variance (ANOVA) using Software Statgraphics Plus for Windows v. 5.2 (Manugistics, Inc., Rockville, MO, USA) to test the effect of different cheese type on cheese parameters. The effect of storage time on the cheese characteristics was studied using the Statistical program (StatSoft, Inc, 2010).

\section{Results and Discussion}

\section{Enumeration of microorganisms}

The microbiological results 1 day after production and after 25 days of cold storage are shown on table 1. Fresh whey cheeses are susceptible to microbial spoilage owing to contamination and sporulation after heat processing of the whey had taken place [29]. As shown in table 1, 1 day of cold storage traditional whey cheese had a total bacterial count (TBC) of $3.61 \log \mathrm{cfu} \mathrm{g}^{-1}$ and yeasts $2.04 \log \mathrm{cfu} \mathrm{g}^{-1}$, while coliforms were not detectable in sample dilution $10^{-1}$ due to the thermal processing of the whey and adequate sanitary conditions during the production of this cheese. Bacteria counted as TBC were thermotolerant, psychrotrophic bacteria, the spores of which are activated immediately after the heat treatment of milk by forming vegetative forms [30]. After 25 days cold storage in traditional whey cheese, the total bacteria increased to $8.94 \log \mathrm{cfu} / \mathrm{g}$, while yeasts increased to $6.28 \mathrm{log} \mathrm{cfu} / \mathrm{g}$ due to the growing of these microorganisms. Also, the coliforms were $7.60 \mathrm{log} \mathrm{cfu} \mathrm{g}^{-1}$. Their presence is possibly attributed to the entry of environmental contaminants during cheese preservation as the traditional whey cheese was wrapped in paper after its production. The microbial content of the traditional whey cheese was in accordance with previously reported data for Myzithra [31] and whey cheese, Anthotyro [5].

On the other hand whey cheese analogue on day 1 had less total bacteria (1.77 log cfu g-1) and also not detectable coliforms on day 25 , due to the packaging of the whey blend in polyethylene bag before heating. So, by the end of cold storage the traditional whey cheese deteriorated as microorganisms were found in higher counts than those of whey cheese analogue and this could be attributed to the different method for packaging for both cheeses. On the contrary, the new whey cheese analogue has a lower microflora when fresh and better sustainability for 25 days.

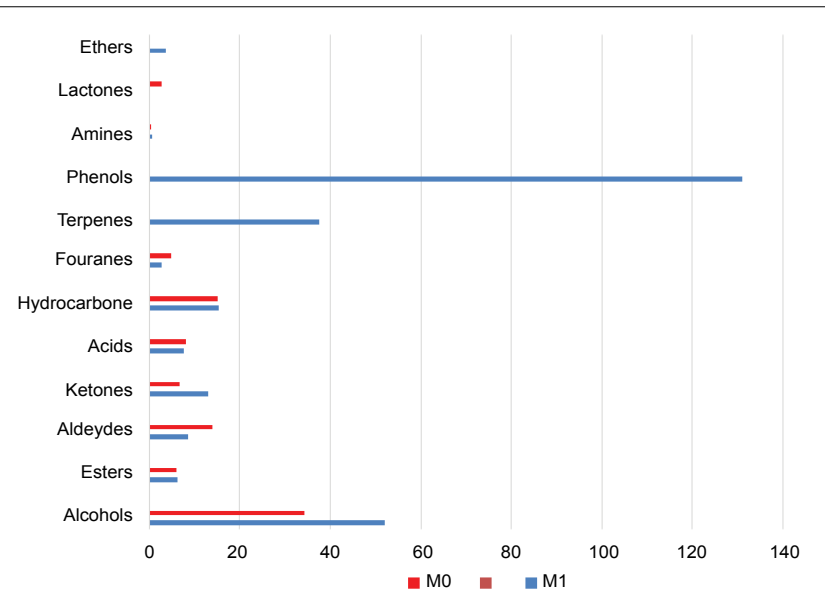

Figure 1: Total chemical groups of the volatile compounds of the two types of whey cheese ${ }^{* *} 1$ day after production*.

*Values are the relative abundance in ppm.

"Mo: traditional whey cheese and M1: whey cheese analogue.

\section{Physicochemical characteristics}

The results of the physicochemical analysis of the 1-day-old cheeses are given in table 2 . There were no significant differences $(\mathrm{P}>0.05)$ in protein, fat and moisture content between the different cheeses. Both of them had a mean moisture content of $67 \%$. The differences $(\mathrm{P}<$ 0.05 ) in ash content found between traditional whey cheese and the whey cheese analogue may be attributed to differences in the mineral content of the mixture. Calcium was higher in traditional whey cheese, but potassium and sodium content were present in greater amounts in the whey cheese analogue due to the composition of the added WPC. The higher mean lactose content $(4.66 \%)$ in the whey cheese analogue can be attributed to the composition of the added WPC and milk powder.

No significant differences $(\mathrm{P}>0.05)$ in the physicochemical characteristics were found between day 1 and day 25, apart from the $\mathrm{pH}$ values which decreased significantly due to microbial growth ( $\mathrm{P}$ $<0.05)$. 25-day-old traditional whey cheese had a lower $\mathrm{pH}(5.17)$ than the corresponding whey cheese analogue (5.72) due to its higher bacteria population.

\section{Volatile compounds}

The volatile compounds included alcohols, esters, aldehydes, acids, ketones, terpenes, fouranes, hydrocarbons, phenols, lactones, ethers and amines, and their relative abundance is presented in figure 1. Most of them have been previously reported for whey cheese Myzithra [32]. Alcohols were the most abundant compounds in traditional whey cheese accounting for $37.07 \%$, followed by hydrocarbons, aldehydes, acids and ketones. In the whey cheese analogue, phenols thymol and carvacrol, which are the principal volatiles of thyme leaves [33], accounted for $47.02 \%$ of the total VOC of this cheese, giving it a characteristic flavor, followed by alcohols (18.66\%) and terpenes (13.50\%). The high level of alcohols could be attributed to their production from many metabolic pathways such as lactose metabolism, methyl ketone reduction, amino acid metabolism and the degradation of linoleic and linolenic acids [34].

\section{Fatty acids profile}

The percentages of fatty acids of cheeses on day 1 are shown in table 3 and classified as Saturated Fatty acids (SFA), Mono-unsaturated Fatty acids (MUFA) and Poly-unsaturated Fatty acids (PUFA). It is known that the SFA are potentially harmful to humans, especially with respect to coronary heart disease [8]. The percentage of SFA in the whey cheese analogue was lower compared to the traditional whey cheese $(50 \%$ and $68.5 \%$ respectively), with palmitic, stearic and myristic acids dominating. In addition, the percentage of low molecular fatty acids $\mathrm{C} 4-\mathrm{C} 10$ in the whey cheese analogue was just $0.28 \%$ as 
milk fat was replaced by vegetable oil, while in traditional whey cheese it was $17.97 \%$. The new cheese analogue had a higher percentage of MUFA and PUFA (34\% and $15.5 \%$ respectively), containing oleic acid, linoleic (LA) and dihomo- $\gamma$-linolenic acid (DGLA) in the highest amounts. The above omega- 6 fatty acids are well-known for their beneficial properties in human health, as they reduce total and LDL cholesterol levels and protect against heart diseases [35].

\section{Textural assessment}

Instrumental texture profile analysis indicated differences between the two types of whey cheese in texture attributes, except elasticity (Table 4). Thus on day 1 the whey cheese analogue was softer, less cohesive, gummier, adhesive and chewier than traditional whey cheese. Milk fat in traditional whey cheese gave a more compact and continuous protein matrix. In contrast, when vegetable oil was used in the whey cheese analogue, a looser, less

Table 3: Percentages of fatty acids (\% fatty acids / of total fat) of the two types of whey cheese 1 day after production.

\begin{tabular}{|c|c|c|c|}
\hline Fatty acid & & $\begin{array}{l}\text { Traditional } \\
\text { whey cheese }\end{array}$ & $\begin{array}{l}\text { Whey cheese } \\
\text { analogue }\end{array}$ \\
\hline & SFA $^{*}$ & & \\
\hline Butiric acid & $\mathrm{C}_{4}$ & 4.17 & 0.00 \\
\hline Caproic acid & $\mathrm{C}_{6}$ & 2.99 & 0.01 \\
\hline Caprylic acid & $\mathrm{C}_{8}$ & 3.12 & 0.10 \\
\hline Capric acid & $\mathrm{C}_{10}$ & 7.69 & 0.17 \\
\hline Lauric acid & $\mathrm{C}_{12}$ & 3.59 & 0.92 \\
\hline Myristic acid & $\mathrm{C}_{14}$ & 10.73 & 1.29 \\
\hline Pentadecanoic acid & $\mathrm{C}_{15}$ & 0.82 & 0 \\
\hline Palmitic acid & $\mathrm{C}_{16}$ & 28.06 & 38.72 \\
\hline Nacre acid & $C_{17}$ & 0.4 & 0.07 \\
\hline Stearic acid & $\mathrm{C}_{18}$ & 6.97 & 3.46 \\
\hline Arachidonic acid & $\mathrm{C}_{20}$ & 0.00 & 0.62 \\
\hline \multirow[t]{2}{*}{ Eicosanoic acid } & $\mathrm{C}_{21}$ & 0.00 & 4.95 \\
\hline & MUFA $^{*}$ & & \\
\hline Myristoleic acid & $\mathrm{C}_{14: 1}$ & 0.42 & 0.03 \\
\hline Palmitoleic acid & $C_{16: 1}$ & 1.06 & 0.17 \\
\hline \multirow[t]{2}{*}{ Oleic acid } & $\mathrm{C}_{18: 1 \text { (cis-9) }}$ & 25.42 & 34.04 \\
\hline & PUFA $^{*}$ & & \\
\hline a-Linoleic acid & $\mathrm{C}_{18: 2 \text { (cis-9, cis-12) }}$ & 2.69 & 11.63 \\
\hline a-Linolenic acid & $\mathrm{C}_{18: 3 \text { (cis-9, cis-12, cis-15) }}$ & 0.15 & 0.09 \\
\hline Dihomo-y-linolenic acid & $\mathrm{C}_{20: 3}$ & 0.00 & 3.73 \\
\hline \multirow[t]{2}{*}{$\mathrm{CLA}^{* *}$} & $\mathrm{C}_{18: 2 \text { (cis-9, trans-11) }}$ & 1.73 & 0 \\
\hline & Total & 100 & 100 \\
\hline
\end{tabular}

'SFA: Saturated Fatty acids, MUFA: Mono-unsaturated Fatty acids, PUFA: Polyunsaturated Fatty acids

${ }^{*}$ CLA: Conjugated linoleic acid dense and therefore weaker and more disrupted protein matrix was formed. This was due to the low melting point of vegetable fat and oleic acid resulting in the presence of more numerous droplets, in comparison with the higher melting point of milk-fat, which resulted in fewer globules [11]. Consequently, the whey cheese analogue was characterized by reduced hardness, chewiness and cohesiveness [36]. The lower lever of the above parameters could also be attributed to the lower Ca content. The lower adhesiveness of the whey cheese analogue combined with its high spreading ability could be associated with its high olive oil content. The results for adhesiveness and cohesiveness in traditional whey cheese were in agreement with those from previous studies [32]. With respect to elasticity, both cheeses exhibited similar elasticity values, although this property is largely unimportant for whey cheese.

After 25 days of storage, no significant $(\mathrm{P}>0.05)$ decrease in all the rheological parameters of traditional whey cheese was observed due to proteolysis, whereas in whey cheese analogues most of these parameters increased substantially. Proteolysis disrupts the structural integrity of the protein matrix, leading to reduced firmness cohesiveness and chewiness [37].

\section{Organoleptic evaluation}

The results of the organoleptic evaluation are presented in table 5. Whey cheese analogues containing vegetable fat could be sliced similarly to traditional whey cheese but was softer, had a yellowish color because of the vegetable fat used and a characteristic thyme flavor due to the added thyme leaves. Although the scores awarded by the taste panel were lower for the whey cheese analogues than for traditional whey cheese on day 1 for all the attributes evaluated $(\mathrm{P}<$ 0.05 ), the total score of the former was nevertheless quite high (78$91 \%)$.

There were no significant $(\mathrm{P}>0.05)$ differences in any of the organoleptic characteristics of the whey cheese analogues after 25 days of storage. On the contrary, traditional whey cheese on day 25 received a lower overall score $(\mathrm{P}<0.05)$ than on day 1 , since it had developed an acid taste and substandard texture due to the proteolytic and lipolytic activities of aerobic and psychrotrophic bacteria, which are usually responsible for the production of many metabolites leading to the development of off-flavours in foods [30].

\section{Conclusion}

A whey cheese analogue was successfully and easily manufactured using as basic ingredients whey protein concentrate WPC 65 and vegetable fat with $15 \%$ olive oil in fat. The final product resembled the traditional whey cheese in physicochemical composition but had increased unsaturated fats, a richer aromatic profile, lower microflora and better keeping quality during cold storage.

Table 4: Rheological characteristics of the two types of whey cheese 1 day after production and after 25 day's storage*.

\begin{tabular}{|c|c|c|c|c|}
\hline \multirow{2}{*}{ Rheological characteristics } & \multicolumn{2}{|c|}{ Traditional whey cheese } & \multicolumn{2}{|c|}{ Whey cheese analogue } \\
\hline & Day 1 & Day 25 & Day 1 & Day 25 \\
\hline Hardness $(\mathrm{N})$ & $4.60^{b} \pm 0.21$ & $4.23^{b} \pm 0.29$ & $1.39^{a} \pm 0.15$ & $1.87^{a} \pm 0.19$ \\
\hline Elasticity (mm) & $1.13^{a} \pm 0.10$ & $1.00^{\mathrm{a}} \pm 0.001$ & $1.01^{\mathrm{a}} \pm 0.01$ & $1.05^{a} \pm 0.05$ \\
\hline Cohesiveness (N.mm) & $0.45^{b} \pm 0.02$ & $0.43^{b} \pm 0.02$ & $0.38^{a} \pm 0.01$ & $0.43^{b} \pm 0.02$ \\
\hline Adhesiveness (N.mm) & $14.93^{c} \pm 2.26$ & $12.63^{c} \pm 2.13$ & $5.24^{a} \pm 0.67$ & $8.6^{b} \pm 1.23$ \\
\hline Gumminess (N.mm) & $2.05^{b} \pm 0.08$ & $1.89^{b} \pm 0.15$ & $0.53^{a} \pm 0.06$ & $0.8^{a} \pm 0.13$ \\
\hline Chewiness (N.mm) & $2.29^{d} \pm 0.11$ & $1.89^{c} \pm 0.15$ & $0.54^{a} \pm 0.06$ & $0.8^{b} \pm 0.05$ \\
\hline
\end{tabular}

*Values are means \pm standard error of mean. Different letters $(a, b, c, d)$ in the same row are indicative of a significant statistical difference $(P<0.05)$ between the values.

Table 5: Organoleptic evaluation of the two types of whey cheese 1 day after production and after 25 day's storage*.

\begin{tabular}{|c|c|c|c|c|}
\hline \multirow{2}{*}{ Organoleptic characteristics } & \multicolumn{2}{|c|}{ Traditional whey cheese } & \multicolumn{2}{|c|}{ Whey cheese analogue } \\
\hline & Day 1 & Day 25 & Day 1 & Day 25 \\
\hline Texture $(0-40)$ & $37.05^{\complement} \pm 0.13$ & $34.72^{b} \pm 0.10$ & $30.52^{\mathrm{a}} \pm 0.21$ & $31.20^{\mathrm{a}} \pm 1.18$ \\
\hline Taste $(0-50)$ & $44.80^{\circ} \pm 0.20$ & $28.33^{\mathrm{a}} \pm 2.73$ & $40.16^{b} \pm 0.37$ & $41.04^{b} \pm 1.20$ \\
\hline Color $(0-10)$ & $9.58^{c} \pm 0.10$ & $8.78^{b} \pm 0.15$ & $7.78^{a} \pm 0.47$ & $8.01^{\mathrm{a}} \pm 0.13$ \\
\hline Total $(0-100)$ & $91.43^{c} \pm 1.56$ & $71.83^{\mathrm{a}} \pm 2.63$ & $78.46^{b} \pm 2.97$ & $80.24^{b} \pm 2.21$ \\
\hline
\end{tabular}

*Values are means \pm standard error of mean. Different letters $(a, b, c)$ in the same row are indicative of a significant statistical difference $(P<0.05)$ between the values. 


\section{References}

1. Guinee TP, Caric M, Kalab M (2004) Pasteurized processed cheese and substitute/imitation cheese products. Elsevier 2: 349-394.

2. Bachmann H (2001) Cheese analogues - A review. Int Dairy11: 505-515.

3. Pearce R J (1989) Thermal denaturation of whey proteins. IDF Bull 238: 1723.

4. Anifantakis EM (1991) Greek Cheeses: A Tradition of Centuries. National Dairy Committee of Greece, Athens, Greece.

5. Kalogridou-Vasiliadou D, Tzanetakis N, Litopoulou-Tzanetaki E (1994) Microbiological and physicochemical characteristics of 'Anthotyro', a Greek traditional whey cheese. Food Microbiology 11: 15-19.

6. Lioliou K, Litopoulou-Tzanetaki E, Tzanetakis N, Robinson RK (2001) Changes in the microflora of manouri, a traditional Greek whey cheese during storage. Int J Dairy Technol 54: 100-106.

7. Smithers GW (2008) Whey and whey proteins from 'gutter-to-gold'. Int Dairy J 18: 695-704.

8. Micha R, Dariush M (2010) Saturated Fat and Cardio metabolic Risk Factors, Coronary Heart Disease, Stroke, and Diabetes: a Fresh Look at the Evidence. Lipid 45: 893-905.

9. Yu L, Hammond EG (2000) Production and characterization of a Swiss cheese-like product from modified vegetable oils. J Am Oil Chem Soc 77 917-924.

10. Katsiari MC, Voutsinas LP, Kondyli E (2002) Improvement of sensory quality of low-fat Kefalograviera-type cheese with commercial adjunct cultures. In Dairy J 12: 757-764.

11. Lobato-Calleros C, Velazquez-Varela J, Sanchez-Garcva J, Vernon-Carte EJ (2003) Dynamic rheology of mexican manchego cheese like products containing canola oil and emulsifier blends. Food Res Int 36: 81-90.

12. Baraka A, Abd El-Salam (2015) Effect of Milk Fat Replacement with Vegetable Oil and/or Whey Protein Concentrate on Microstructure, Texture and Sensory Characteristics of Fresh Soft Cheese. Int J Dairy Sci 10: 117-125

13. Anifantakis EM (1991) Greek Whey cheeses. In: Greek cheeses a tradition of centuries. National Dairy Committee of Greece, Athens, Greece 89.

14. Anifantakis EM, Kaminarides S E (1983) Contribution to the study of Halloum cheese made from sheep's milk. Aust J Dairy Technol 38: 29-31.

15. International Dairy Federation (1991) Milk and milk products - Enumeration of microorganisms (Colony count technique at $30^{\circ} \mathrm{C}$ ). Standard $100 \mathrm{~B}$, Brussels Belgium.

16. International Dairy Federation (1991) Enumeration of yeasts and moulds. Standard 94B, Brussels, Belgium.

17. International Dairy Federation (1985) Enumeration of coliforms. Standard 73B, Brussels, Belgium.

18. International Dairy Federation (2008) Milk: Determination of nitrogen content Standard 4A, Brussels, Belgium.

19. International Dairy Federation (1982) Determination of dry matter in cheese and processed cheese. Standard 4A Brussels, Belgium.
20. International Dairy Federation (2008) Cheese-determination of fat contentVan Gulik method. Standard 222, Brussels, Belgium.

21. International Dairy Federation (1964) Determination of the ash content of processed cheese products. Standard 27, Brussels, Belgium.

22. AOAC (2000) Association of Official Analytical Chemists. International Officia Methods of Analyses, Washington DC, USA

23. International Dairy Federation (2007) Milk and milk products-Determination of calcium, sodium, potassium and magnesium contents-Atomic absorption spectrometric method. Standard 119, Brussels, Belgium.

24. International Dairy Federation (2007) Milk and milk products: Determination of lactose content by high performance liquid chromatography. Standard 198 Brussels, Belgium.

25. Bligh EG, Dyer WJ (1959) A rapid method for total lipid extraction and purification. Can J Biochem Physiol 37: 911-917.

26. International Dairy Federation (2002) Milk fat: Preparation of fatty acid methy esters. Standard 182, Brussels, Belgium.

27. Kaminarides S, Stachtiaris S (2000) Production of processed cheese using kasseri cheese and processed cheese analogues incorporating whey protein concentrate and soybean oil. Int J Dairy Technol 53: 69-74.

28. International Dairy Federation (1997) Sensory evaluation of dairy products by scoring- reference method. Standard 99C, Brussels, Belgium.

29. Pintado ME, Macedo AC, Malcata FX (2001) Technology, Chemistry and Microbiology of Whey Cheeses. Food Sc Technol Int 7: 105-116.

30. Samaržija D, Zamberlin s, Pogačić T (2012) Psychrotrophic bacteria and milk and dairy products quality. Mljekarstvo 62: 77-95.

31. Kaminarides S, llias-Dimopoulos E, Zoidou E, Moatsou G (2015) The effect of addition of skimmed milk on the characteristics of Myzithra cheeses. Food Chem 180: 164-170.

32. Kaminarides S, Nestoratos K, Massouras T (2013) Effect of added milk and cream on the physicochemical, rheological and volatile compounds of Greek whey cheeses. Small Rumin Res 113: 446-453.

33. Seung-Joo L, Katumi U, Takayuki Sh, Kwang-Geun L (2005) Identification of volatile components in basil (Ocimum basilicum L.) and thyme leaves (Thymus vulgaris L.) and their antioxidant properties. Food Chem 91: 131-

34. Molimard P, Spinnler HE (1996) Review: Compounds Involved in the Flavo of Surface Mold-Ripened Cheeses: Origins and Properties. J Dairy Sci 79 : 169-184.

35. Harris WS, Mozaffarian D, Rimm E, Kris-Etherton P, Rudel LL, et al. (2009) Omega-6 Fatty Acids and Risk for Cardiovascular Disease. Circulation 119 902-907

36. Lobato-Calleros C, Sosa-Perez A, Rodriguez-Tafoya J, Sandoval-Castilla O, Perez-Alonso C, et al. (2007) Structural and textural characteristics of reduced-fat cheese-like products made from W1/O/W2 emulsions and skim milk. LWT - Food Sc Technol 41: 1847-1856.

37. Awad S, Hassan AN, Muthukumarappan K (2005) Application of Exopolysaccharide-Producing Cultures in Reduced-Fat Cheddar Cheese: Texture and Melting Properties. J Dairy Sci 88: 4204-4213. 